до роботи в наукових проблемних групах під керівництвом викладачів фахових дисциплін. Науково-дослідна робота має спрямовуватися на формування та розвиток умінь науководослідної роботи та передбачає: набуття вмінь та навичок самостійного пошуку інформації, формування вмінь користування науково-технічними засобами, умінь аналізувати, систематизувати, узагальнювати набуту інформацію, робити висновок, оволодіння методиками, методами, прийомами та засобами науково-педагогічних досліджень.

За навчальним планом написання курсових робіт виконується студентами у 7 семестрі, до проходження ними виробничої педагогічної практики. На нашу думку, такий порядок організації фахової підготовки унеможливлює виконання студентами науково-дослідної роботи, оскільки студенти хоча й мають досвід початкового ознайомлення з педагогічним процесом та практикою шкільної роботи, яку вони отримують на пасивній навчальній практиці у 4 семестрі, але не $\epsilon$ готовими до виконання такого доволі складного виду наукової діяльності, яким є написання курсової роботи. Усе це призводить до втрати системності та послідовності у процесі фахової підготовки, набуття нею формального абстрактного характеру, не сприяє усвідомленню студентами важливості та значення науково-дослідної діяльності для формування власної професійної і творчої компетентності.

Підвищення результативності фахової підготовки у формуванні творчої компетентності майбутніх учителів іноземної мови пов'язано з: особистісно-гуманістичною спрямованістю всієї системи; формуванням усіх структурних компонентів, що розкривають зміст професійної та творчої компетентності майбутніх вчителів; сприянням формуванню творчих якостей студентів у іiі процесі; систематичним моніторингом, контролем, самоконтролем та самооцінкою навчальних досягнень і результатів професійного росту студентів.

Ефективність формування творчої компетентності майбутніх учителів іноземної мови в процесі їх фахової підготовки зумовлена виявленням дидактичних умов та подоланням суперечностей між вимогами, що висуваються до особистості та діяльності майбутнього вчителя та фактичним рівнем творчої компетентності, між типовою системою фахової підготовки та особистісною сутністю творчої компетентності. Стан досліджуваної проблеми формування творчої компетентності майбутніх учителів іноземної мови вимагає подальших наукових пошуків. Детального розгляду потребують: методики діагностування рівня сформованості творчої компетентності майбутнього вчителя, показників та критеріїв ії сформованості, розроблення моделі та технології ії формування.

\title{
Література
}

1. Ніцой А. І. 3 досвіду підготовки вчителя в сучасних умовах / А. І. Ніцой // Вопросы научной и профессионально-педагогической подготовки учителя. - Херсон : ХПИ им. Н. К. Крупской, 1991. С. 3-6. 2. Пахомова О. В. Креативність як ознака професійної компетентності майбутніх учителів іноземної мови / О. В. Пахомова // Теорія і практика проектування авторських педагогічних систем: [зб. матеріалів всеукр. науково-практ. конференції]. - К. : Інститут обдарованої дитини НАПН України, 2012. - С. 239-243. 3. Пахомова О. В. Проблема формування творчої компетентності майбутніх учителів іноземної мови в науковій літературі / О. В. Пахомова // Вища освіта України. Додаток 1 до вип. 27. Том II (35). - К. : Гнозис, 2012. - Тематичний випуск «Вища освіта України у контексті інтеграції до європейського освітнього простору». - С. 215-221. 4. Пахомова О.В. Формування професійної компетентності майбутніх учителів філологічних дисциплін у процесі загальнопедагогічної підготовки: дис. ... канд. пед. наук: 13.00 .04 / О. В. Пахомова. - Кіровоград; Кіровоградський державний пед. університет ім. В. Винниченка, 2011. - 264 с.

\section{РОБОЧИЙ ЗОШИТ ЯК ДИДАКТИЧНИЙ ЗАСІБ ПІДГОТОВКИ МАЙБУТНІХ УЧИТЕЛІВ ДО РЕАЛІЗАЦІЇ ДИФЕРЕНЦЙОВАНОГО ПІДХОДУ В НАВЧАННІ МОЛОДШИХ ШКОЛЯРІВ}

Прокоф’єва М. Ю. Робочий зошит як дидактичний засіб підготовки майбутніх учителів до реалізації диференційованого підходу в навчанні молодших школярів.

У статті розглядається робочий зошит як важливий предметно-знаковий засіб навчання, що отримав загальне визнання у викладачів і студентів. Навчальна діяльність у ньому спеціально конструюється і відбивається в певній логіці. Використання робочого зошита полегшує 
педагогові планування заняття, дозволяє поєднувати усну і письмову роботу, позбавляє студентів від великого обсягу механічної роботи, а також сприяє індивідуалізації процесу навчання.

Ключові слова: самостійна робота студентів, робочий зошит, освітній процес.

Прокофьева М. Ю. Рабочая тетрадь как дидактическое средство подготовки будущих учителей к реализации дифференцированного подхода в обучении младших школьников.

В статье рассматривается рабочая тетрадь как важное предметно-знаковое средство обучения, получившее общее признание у преподавателей и учащихся. Учебная деятельность в нем специально конструируется и отражается в определенной логике. Использование рабочей тетради облегчает педагогу планирование занятия, позволяет сочетать устную и письменную работу, избавляет студентов от большого объема механической работы, а также способствует индивидуализации процесса обучения.

Ключевые слова: самостоятельная работа студентов, рабочая тетрадь, образовательный процесс.

Prokofieva M. Yu. Workbook as a didactic means of preparing future teachers to implement a differentiated approach in teaching younger students.

The workbook is an important subject-signicant learning tool that has received general acceptance from teachers and students. The workbook activities are specically designed and is reected in a certain logic. Using a workbook facilitates teacher lesson planning, allows to combine oral and written work, saves students from a large amount of mechanical work, and also promotes learning process individualization.

Key words: independent work of students, a workbook, the educational process.

Ефективними шляхами підготовки майбутнього спеціаліста відповідно до вимог Болонського процесу $\epsilon$ формування у студентів усвідомленої потреби в постійному професійному самовдосконаленні, розвитку творчого потенціалу та професійного мислення, створенню умов для самостійного здобуття знань, умінь та навичок їх застосування на практиці. Цьому значною мірою сприяє ефективна самостійна робота, яка надає змогу студентам закріплювати здобуті знання та застосувати їх на практиці, приймаючи рішення без сторонньої допомоги. Самостійна робота студентів потребує чітко продуманого організаційнометодичного супроводу з боку викладача. Важливо, щоб викладач не тільки надавав своєчасну допомогу в розв'язанні завдань самостійної роботи, але i сприяв цілеспрямованому формуванню в них знань і вмінь щодо ії організації.

Питання керівництва та планування самостійної роботи досліджували С. Архіпова, В. Буряк, В. Вертегел, Н. Дайрі, Б. Ссипов, Л. Жарова, Л. Журавська, А. Іванівська, Н. Калашник, Г. Майборода, П. Підкасистий та ін. Найбільш широко досліджено цю проблему крізь призму пізнавальної самостійності й ролі студента в її здійсненні (А. Алексюк, Г. Костюк, О. Конопкін, О. Мороз, А. Молибог, О. Скрипченко, Н. Сидорчук, В. Онищук, О. Осницький та ін.). Сучасні наукові розвідки зосереджені на вивченні питань розвитку самостійності під час позааудиторної діяльності (О. Дубасенюк, Л. Клименко, В. Лозова), а також пошуку різних підходів до класифікації самостійної роботи та визначення провідних методів ії здійснення (С. Вітвицька, І. Зимня, А. Кузьмінський, 3. Курлянд, В. Нагаєв).

Зміна парадигми освіти від передавання «готових знань» до парадигми формування компетенцій передбачає реалізацію не тільки нових підходів до організації самостійної роботи студентів, а й створення сучасних дидактичних засобів, що сприяють підвищенню мотивації студентів до здійснення самостійної роботи, володіють не тільки набором нових функцій, але й об’єднують в одному дидактичному засобі функції кількох засобів навчання. Використання дидактичних засобів у самостійній роботі студентів сприяє її системній організації, успішному засвоєнню змісту навчальної дисципліни студентами, формуванню компетенцій відповідно до вимог державних стандартів освіти.

Розв'язання проблеми дидактичних засобів, трактування цього поняття, визначення функцій, виявлення їх ролі в навчально-методичному комплексі у процесі організації самостійної роботи здійснювалося в дисертаційних дослідженнях О. Васильєвої, О. Єрмакової, Є. Ільїної, Т. Річкіна, О. Сеніна, О. Ямщикова та ін. Проблеми створення, застосування дидактичних засобів у процесі навчання розглядали такі науковці, як В. Беспалько, Н. Бордовська, Л. Зоріна, В. Симоненко, Ю. Татур, М. Холодна, Н. Шубіна. 
Одним із важливих предметно-знакових засобів навчання, що набули останнім часом загального визнання у викладачів і студентів, $є$ робочий зошит, навчальна діяльність у якому спеціально конструюється і відбивається в певній логіці. Сучасний робочий зошит - це дидактичний комплекс, призначений для самостійної роботи студентів на аудиторному практичному занятті, а також у позаурочний час безпосередньо на його сторінках. Використання робочого зошита полегшує педагогові планування заняття, дозволяє поєднувати усну і письмову роботу, позбавляє студентів від великого обсягу механічної роботи, а також сприяє диференціації та індивідуалізації процесу навчання. Структура робочого зошита може бути різною, що зумовлено змістом досліджуваного предмета, ступенем його складності, вихідним рівнем підготовки аудиторії, умовами навчання, творчими особливостями викладача. Призначення робочого зошита полягає в тому, щоб допомогти студентам в засвоєнні важкого для них теоретичного курсу, показати можливі методи і прийоми аналізу матеріалу. Виконання вправ, розв'язання задач, читання навчальної та наукової літератури сприяє розвитку самостійного мислення студентів, тому викладач повинен надати можливість студентам самим знайти рішення й аргументувати його, залучаючи теоретичні знання, засвоєні на лекціях, i додатковий матеріал.

Мета статті - розглянути робочий зошит як дидактичний засіб у системі професійної підготовки майбутнього вчителя початкових класів, що допомагає йому оволодіти готовністю до реалізації диференційованого підходу в навчанні молодших школярів.

Робочий зошит (авторська розробка) ми використовували під час викладання спецкурсу «Індивідуалізація та диференціація навчання молодших школярів», метою якого було оволодіння майбутніми вчителями початкових класів інтегрованими знаннями та вміннями 3 проблеми організації індивідуалізації та диференціації навчання на основі системних змін у теоретичній і практичній підготовці.

Робочий зошит виконує такі методичні функції: дозволяє більш ефективно використовувати час практичних та індивідуальних занять й оптимізовувати самостійну роботу студентів; стимулює й активізує розумову діяльність студентів; створює умови для управління навчальним процесом з боку викладачів.

Під час створення робочого зошита нами враховані методичні підходи до здійснення контролю навчальних досягнень студентів. Він містить різнорівневі завдання і запитання для самостійної роботи та підготовки до практичних занять; творчі завдання, які $є$ різновидом проектної діяльності; завдання для поточного контролю. Завдання вміщено за темами програми спецкурсу і об'єднано в межах кожної у два розділи - завдання для самостійної роботи та завдання й тести для поточного контролю.

Робочий зошит побудований за такою структурою: орієнтаційно-мотиваційний компонент, операційно-виконавчий компонент, рефлексивно-оцінний компонент.

Орієнтаційно-мотиваційний компонент представлений робочою програмою та тематичним планом спецкурсу, описом знань та умінь, що формуються в межах теми, основними теоретичними питаннями до практичного заняття, джерелами інформації, критеріями оцінювання, питаннями до заліку.

Операційно-виконавчий компонент представлений контрольними питаннями, темами рефератів та презентацій, алгоритмічними приписами до написання рефератів та створення презентацій, а також системою різнорівневих вправ, приклади яких наведено в табл. 1.

Табличя 1

Класифікація завдань за змістом

\begin{tabular}{|l|l|}
\hline \multicolumn{1}{|c|}{ Завдання } & \multicolumn{1}{|c|}{ Приклад } \\
\hline Глосарій & $\begin{array}{l}\text { Користуючись педагогічними та психологічними словниками, розкрийте зміст понять: } \\
\text { iндивідуалізація навчання, індивідуальний підхід, диференціація навчання, } \\
\text { диференційоване навчання, диференційований підхід, напрями, види, ступінь } \\
\text { диференціації, рівнева диференціація, профільна диференціація }\end{array}$ \\
\hline $\begin{array}{l}\text { Складання } \\
\text { схем }\end{array}$ & $\begin{array}{l}\text { Ознайомившись 3 матеріалами лекції та посібника, запропонуйте структурно-логічну } \\
\text { схему «Класифікація диференційованих завдань в початковій освіті» }\end{array}$ \\
\hline $\begin{array}{l}\text { Заповнення } \\
\text { таблиць та схем }\end{array}$ & $\begin{array}{l}\text { Заповніть таблицю «Форми дезадаптації, причини та коригувальні заходи щодо ії } \\
\text { подолання у молодших школярів» }\end{array}$ \\
\hline
\end{tabular}




\begin{tabular}{|c|c|}
\hline $\begin{array}{l}\text { Аналіз } \\
\text { інформації }\end{array}$ & $\begin{array}{l}\text { Академік Ю. Бабанський причини неуспішності учнів убачає у слабкому розвитку } \\
\text { мислення - } 27 \% \text {; низькому рівні навичок навчальної праці - } 18 \% \text {; негативному } \\
\text { ставленні до навчання - } 14 \% \text {; негативному впливі сім'ї, однолітків - 13\%; великих } \\
\text { прогалинах у знаннях - } 11 \% \text {; слабкому здоров’ї, втомлюваності - } 9 \% \text {; слабкій волі, } \\
\text { недисциплінованості }-8 \% \text {. Якою є Ваша позиція з цього приводу? } \\
\end{array}$ \\
\hline $\begin{array}{l}\text { Доповнення } \\
\text { речення }\end{array}$ & $\begin{array}{l}\text { Для діагностування гіперактивності необхідна наявність принаймні } 5 \text { з перерахованих } \\
\text { нижче симптомів. Дитина } є \text { гіперактивною, якщо вона: } \\
\text { 1. Робить рухи руками й ногами. } \\
\text { 2. Гіперрухлива у ситуаціях, коли гіперрухливість неприйнята } \\
\text { 3. } \\
\text { 4. } \\
\text { 5. }\end{array}$ \\
\hline $\begin{array}{l}\text { Розв'язання } \\
\text { психологічної } \\
\text { задачі }\end{array}$ & $\begin{array}{l}\text { «Як визначити, чи готова дитина до навчання у школі? Особливо зараз, коли можна } \\
\text { віддавати ії до школи і в } 6, \text { і в } 7 \text { років. Я хотіла б віддати свого шестирічного сина до } \\
\text { школи, але мені не радять вихователі. Та й дитина не виявляє великого бажання } \\
\text { вчитись», - засмучується мама майбутнього школяра. Такі запитання ставлять багато } \\
\text { батьків. Як визначити психологічну готовність дітей до навчання у школі? Чи можна } \\
\text { передбачити, як дитина буде навчатись? }\end{array}$ \\
\hline $\begin{array}{l}\text { Практичне } \\
\text { завдання }\end{array}$ & $\begin{array}{l}\text { Доберіть диференційовані завдання для групової та індивідуальної роботи в класі } \\
\text { (виберіть клас, предмет, тему, використовуючи календарне планування і зміст } \\
\text { навчального комплекту). }\end{array}$ \\
\hline $\begin{array}{l}\text { Проектне } \\
\text { завдання }\end{array}$ & $\begin{array}{l}\text { Підготуйте репортаж } 3 \text { фото- та відеофрагментами щодо впровадження технологій } \\
\text { індивідуалізації та диференціації навчання в початковій школі. }\end{array}$ \\
\hline
\end{tabular}

Рефлексивно-оцінний компонент представлений у вигляді тестових завдань різного рівня складності для поточного контролю знань студентів. Завдання розміщено у порядку зростання складності за чотирма рівнями.

Початковий рівень - тестові завдання, що передбачають вибір однієї правильної відповіді (наприклад, У XX столітті в практиці шкіл були випробувані різні види диференщіації. Серед них: А) диференціація за здібностями; Б) диференціачія за інтелектом; В) диференціація за нездатністю. Яка з иих класифікацій диференціації навчання нині не застосовується?).

Середній рівень має два завдання: одне на встановлення відповідності (наприклад, Класифікуйте основні способи зовнішньої (1) $і$ внутрішньої (2) диференціації навчання: A) варіативність темпу вивчення навчального матеріалу; Б) створення на основі здібностей та інтересів учнів відносно стійких груп; В) вибір учнем класу з поглибленим вивченням певного циклу предметів; Г) диференціація навчальних завдань; Д) вибір різних видів діяльності; Ж) визначення характеру i ступеня допомоги з боку вчителя; 3) вибір факультативів) або на перевірку вміння формулювати визначення (наприклад, Розкрийте зміст понять: 1. Функиіональна готовність дитини шестирічного віку до нових для неї умов шкільного навчання передбачає__ ); друге - передбачає вибір з наведеного переліку варіантів відповідей (наприклад, Назвіть педагогічно грамотні прийоми корекиії неуспішності навчання, викормивши їх із загального списку прийомів: А) формування навичок навчальної праці $і$ мислення; Б) намагання підвищити відповідальність дитини матеріальним заохоченням; В) змінення мотивації навчання; Г) використовування погроз, покарання, недоброзичливої критики; Д) застосування дисииплінарного вилив директора начального закладу; Ж) передбачення завдань зі зниженою складністю, формування позитивного ставлення до самостійної прачі; 3) ігнорування функиіональної слабкості вищої нервової діяльності школяра; K) дотримання відповідності зростання вимог до дітей зростанню їхніх можливостей реалізувати циі вимоги; застосування прийому підказок, навідних відповідей).

Достатній рівень містить завдання на заповнення таблиці та одне теоретичне запитання (наприклад, Використовуючи ключові слова (дані в дужках), сформулюйте цілі диференціації: 3 соціальної точки зору (потенціал суспільства); з дидактичної точки зору (школа); з психологопедагогічної точки зору (здатності).

Високий рівень охоплює завдання творчого характеру (наприклад, Доберіть стандартизовані методи, проективні методики для виявлення особливостей пізнавальних 
процесів у молодших школярів й апробуйте їх на практиці (на прикладі таких пізнавальних процесів, як сприймання, уваги, мислення, пам'ять, уява).

Використання в процесі викладання спецкурсу робочого зошита сприяло формуванню у студентів умінь співвідносити теоретичний стан проблеми диференційованого навчання 3 практичним; використовувати основні форми, методи, засоби реалізації диференційованого підходу; реалізовувати принцип диференційованого підходу в процесі спільної діяльності вчителя й учня; встановлювати рівень розвитку пізнавальних можливостей і здібностей учнів; виокремлювати й діагностувати індивідуально-психологічні особливості учнів; володіти сукупністю інформативних методик, що дозволяють реалізовувати диференційований підхід; використовувати нові технологічні методи перевірки й оцінки знань учнів в умовах диференційованого підходу.

Методикою передбачалось, що більшість завдань можуть виконати всі студенти, використовуючи в разі необхідності матеріал навчального посібника [3]. Але для мотивації навчання сильних студентів до кожної теми було внесено завдання, які вимагали більш глибокого осмислення матеріалу, та завдання проблемного характеру.

Отже, можна стверджувати, що робочі зошити є найбільш зручним засобом взаємодії студента з викладачем, оскільки: по-перше, студенти мають змогу готуватися до заняття, як до його теоретичної, так і до практичної частини, а також розібратися в розв'язанні тих прикладів, що залишилися поза заняттям; по-друге, наявність у студентів робочих зошитів не тільки припускає кардинальні зміни у структурі і змісті практичних занять і домашніх завдань, але й дозволяє встановити нову форму звітності студентів про результати роботи.

Ураховуючи викладене вище, перспективу подальшого наукового пошуку в цьому напрямі вбачаємо в розробленні методичних рекомендацій із використання інформаційнокомунікаційних технологій задля розвитку вмінь та навичок самостійної роботи студентів, оскільки це є потужним засобом здійснення не тільки функцій тренінгу, самоконтролю, перевірки знань, а й ефективним способом управління процесом навчання.

\section{Література}

1. Алханов А. Самостоятельная работа студентов / А. Алханов // Высшее образование в России. 2005. - № 11. - С.6-89. 2. Васютіна Т. М. Можливості робочого зошита на друкованій основі у вивченні студентами «Методики викладання курсу «Я і Україна» / Т. М. Васютіна // Науковий часопис НПУ імені М. П. Драгоманова. - 2008. - Вип. 8. - С.21-25. 3. Прокоф'єва М. Ю. Індивідуалізація та диференціація навчання молодших школярів: [навч. посіб. для студ. вищ. навч. закладів] / М. Ю. Прокоф'єва. - Сімферополь: Таврида, 2013. - 224 с.

Людмила Ракімянська

\section{ПРОФЕСІЙНО-ПЕДАГОГІЧНА ОРІЄНТАЦІЯ ВИКОНАВСЬКОЇ ПІДГОТОВКИ МАЙБУТНЬОГО ВЧИТЕЛЯ-МУЗИКАНТА}

Ракітянська Л. М. Професійно-педагогічна орієнтація виконавської підготовки майбутнього вчителя-музиканта.

У статті обгрунтовується актуальність окресленої проблеми. Аналізуються сучасні підходи до ії розвязання, пропонується серія навчальних завдань у процесі індивідуального виконавського опрацювання музичного твору, орієнтованих на потреби шкільної практики.

Ключові слова: музичний твір, виконавська підготовка, індивідуальне навчання, професійно-педагогічна спрямованість.

Ракитянская Л. Н. Профессионально-педагогическая ориентация исполнительской подготовки будущего учителя-музыканта.

В статье обосновывается актуальность проблемы. Анализируются современные подходы к ее решению, предлагается серия учебных задач в процессе индивидуальной работы над музыкальным произведением, направленых на потребности школьной практики.

Ключевые слова: музыкальное произведение, исполнительская подготовка, индивидуальное обучение, профессионально-педагогическая направленность. 